\title{
Problematyka wyliczania wysokości emerytury żołnierzy pełniących służbę w czasie wojny lub w strefie działań wojennych - przyczynek do dyskusji
}

\section{Rules of calculating pensions for soldiers on duty} during war or in war zones - contribution to debate

Streszczenie. Kanwą dla niniejszych rozważań - które w swym założeniu sprowokować mają dyskusję na temat zasad ustalania emerytury żołnierskiej - jest wyrok Sądu Okręgowego w Łodzi z dnia 16 lutego 2018 r. (VIII U 2407/17). W orzeczeniu tym przyjęto, że wyliczając wysokość emerytury żołnierzy pełniących służbę na froncie w czasie wojny lub w strefie działań wojennych, należy poszczególne okresy przeliczać osobno na miesiące. Sumowanie poszczególnych, odrębnych okresów służby w strefie działań wojennych w dniach i zamiana ich na 
pełne miesiące w końcowym podsumowaniu uznane zostały przez sąd za niezgodne z obowiązującym prawem. Orzeczenie to dobrze obrazuje rozbieżności, jakie pojawiają się w praktyce stosowania przepisów przez sądy oraz Wojskowe Biura Emerytalne, a także odnosi się do problemu zgodności rozporządzeń wykonawczych wydawanych w oparciu o przepisy ustawy z dnia 10 grudnia $1993 \mathrm{r}$. o zaopatrzeniu emerytalnym żołnierzy zawodowych oraz ich rodzin (tekst jedn. Dz.U. 2017 poz. 2225) z tą właśnie ustawą.

Słowa kluczowe: wysokość emerytury; zaopatrzenie emerytalne; żołnierz; wojna; strefa wojny.

\begin{abstract}
The basis for considerations included in this article - which is designed to trigger a discussion on rules of calculating soldiers' pensions - is the judgement of February 16, 2018 of the District Court in Łódź (VIII U 2407/17). The court ruled that for the purpose of calculating soldiers' pension, each part of the service of soldiers who served during the war or in the war zone should be recalculated into months. Judges decided that summing individual separate periods of service calculated in days and recalculating them in full months is inconsistent with the law. The judgement of February 16, 2018 depicts well discrepancies in practice of courts and the Army Pension Bureaus. Moreover, that decision relates to the problem of the compatibility of the secondary legislation with the 1993 act on professional soldiers and their families pensions act.
\end{abstract}

Keywords: pension value; pension provision; soldier; war; war zone.

\title{
1. Stan prawny
}

Żołnierze, podobnie jak inne służby mundurowe, podlegają zabezpieczeniu emerytalnemu na zupełnie odrębnych ${ }^{1} \mathrm{w}$ stosunku do systemu powszechnego zasadach ${ }^{2}$. Jest to system zaopatrzeniowy, określony ponadto

1 Drugą grupą społeczną, której regulacje w zakresie kwestii zabezpieczenia emerytalnego określone zostały w odrębnej ustawie, są rolnicy - Ustawa z dnia 20 grudnia 1990 r. o ubezpieczeniu społecznym rolników (tekst jedn. Dz.U. z 2017, poz. 2336).

2 W. Koczur, Zaopatrzenie emerytalne służb mundurowych jako element systemu zabezpieczenia społecznego, „Studia Ekonomiczne” 2017, nr 312, s. 51-55. 
w odrębnej ustawie ${ }^{3}$. Swoistość tego zabezpieczenia zaznacza się najwyraźniej w jego organizacji i finansowaniu ${ }^{4}$.

Zasady ustalania wysokości świadczeń emerytalnych w przypadku żołnierzy oparte są o tzw. zdefiniowane świadczenie i wyliczane na podstawie liczby lat służby wojskowej ${ }^{5}$. Żołnierz ma również prawo do zwiększenia świadczenia w kilku przypadkach niezwiązanych bezpośrednio $\mathrm{z}$ liczbą lat służby. O jednym $\mathrm{z}$ nich stanowi art. 15 ust. 3 ustawy z dnia 10 grudnia 1993 r. o zaopatrzeniu emerytalnym żołnierzy zawodowych oraz ich rodzin (dalej: ustawa o zaopatrzeniu emerytalnym żołnierzy) ${ }^{6}$. Na jego podstawie emeryturę podwyższa się o $0,5 \%$ podstawy wymiaru za każdy rozpoczęty miesiąc pełnienia służby na froncie w czasie wojny lub w strefie działań wojennych. Ponadto Rada Ministrów, uwzględniając miesięczne okresy pełnienia służby na froncie w czasie wojny lub w strefie działań wojennych, określa, w drodze rozporządzenia, szczegółowe warunki podwyższania emerytury (art. 15 ust. 6a pkt 4 ustawy o zaopatrzeniu emerytalnym żołnierzy).

Racjonalny ustawodawca, wprowadzając przepis o określeniu w drodze rozporządzenia (przez Radę Ministrów) szczegółowych warunków podwyższania emerytury, uznał, że sformułowanie znajdujące się w art. 15 ust. 3 ustawy o zaopatrzeniu emerytalnym żołnierzy jest nieostre i wymaga precyzyjnego zdefiniowania, w związku z powyższym odwoływanie się wyłącznie do przepisów ustawy o zaopatrzeniu emerytalnym żołnierzy uznał za niewystarczające. Artykuł 15 ust. 2 ustawy o zaopatrzeniu emerytalnym żołnierzy stanowi, ze emeryturę podwyższa się również o:

3 P. Kuźma, Jakie zmiany w wojskowym systemie emerytalnym?, „Praca i Zabezpieczenie Społeczne” 2010, nr 3, s. 10-16; J. Wantoch-Rekowski, System ubezpieczeń społecznych a budżet państwa: studium prawnofinansowe, Warszawa 2014, s. 55-60.

4 R. Babińska, Systemowe zagadnienia zabezpieczenia emerytalnego wojskowych, „Acta Universitatis Wratislaviensis” 2008, nr 3079, s. 262.

5 M. Czechowski, Prawny charakter zatrudnienia żołnierzy zawodowych, Toruń 2016, s. 258-265; D. Walczak, Przywileje emerytalne - aspekt społeczno-ekonomiczny, „Studia Oeconomica Posnaniensia” 2017, nr 5(10), s. 49-52.

6 Tekst jedn. Dz.U. z 2017, poz. 2225. 
1) 2\% podstawy wymiaru za każdy rok służby pełnionej bezpośrednio:

a) w składzie personelu latającego na samolotach naddźwiękowych,

b) w składzie załóg okrętów podwodnych,

c) w charakterze nurków i płetwonurków,

d) w zwalczaniu fizycznym terroryzmu;

2) $1 \%$ podstawy wymiaru za każdy rok służby pełnionej bezpośrednio:

a) w składzie personelu latającego na pozostałych samolotach i śmigłowcach,

b) w składzie załóg nawodnych wojskowych jednostek pływających,

c) w charakterze skoczków spadochronowych i saperów,

d) w służbie wywiadowczej za granicą,

e) w oddziałach specjalnych.

Z kolei artykuł 15 ust. 1 i 1a stanowi o podwyższaniu emerytury w przypadku dodatkowych lat służby lub służby w trakcie urlopu wychowawczego.

Natomiast § 4 Rozporządzenia Rady Ministrów z dnia 15 lipca 2011 r. w sprawie szczegółowych warunków podwyższania emerytur wojskowych $^{7}$ wydanego na podstawie art. 15 ust. 6a ustawy o zaopatrzeniu emerytalnym żołnierzy precyzuje wyłącznie kryterium służby, która jest uznawana przy podwyższaniu świadczenia o $0,5 \%$.

Rozporządzenie Ministra Obrony Narodowej z dnia 10 lutego 2012 r. w sprawie trybu postępowania i właściwości organów w sprawach zaopatrzenia emerytalnego żołnierzy zawodowych oraz uprawnionych członków ich rodzin ${ }^{8}$ wydane na podstawie na podstawie art. 37 ustawy o zaopatrzeniu emerytalnym żołnierzy (podstawa prawna będzie istotna w kontekście dalszej analizy zawartej w niniejszym artykule) stanowi o sposobie obliczania wysługi emerytalnej. W § 26 ust. 1. wskazano, że przy obliczaniu wysługi emerytalnej sumuje się poszczególne okresy o jednakowym procentowym wskaźniku, obejmujące lata, miesiące i dni. Sumę dni zamienia się na miesiące, przyjmując za miesiąc trzydzieści dni kalendarzowych. Sumę miesięcy zamienia się na lata, przyjmując pełne 12 miesięcy za jeden rok. W końcowym podsumowaniu okresy niepeł-

Dz.U. Nr 159, poz. 946.

Dz.U. poz. 194. 
nych miesięcy nie są uwzględniane, z wyjątkiem okresów, o których mowa w art. 15 ust. 3 ustawy o zaopatrzeniu emerytalnym żołnierzy.

Ustawodawca w ustawie oraz w rozporządzeniu z 2012 r. szczególnie docenił ciężką służbę na froncie w czasie wojny lub w strefie działań wojennych $^{9}$, wprowadzając przepis o uwzględnieniu w końcowym podsumowaniu również niepełnych okresów wynikających ze służby na wojnie (art. 15 ust. 3 ustawy o zaopatrzeniu emerytalnym żołnierzy). Przepis ten nie dotyczy żadnej z innych regulacji dotyczącej prawa do podwyższenia świadczenia z tytułu służby w warunkach specjalnych, nawet w odniesieniu do prac, w których uwzględnia się okresy roczne.

\section{Zasady obliczania wysokości emerytury w ocenie Sądu Okręgowego}

Stan faktyczny, który stał się podstawą wydania orzeczenia Sądu Okręgowego w Łodzi, dotyczył ustalania liczby miesięcy pełnienia służby w szczególnych warunkach. Dyrektor Wojskowego Biura Emerytalnego w Ł. decyzją z dnia 24 października 2017 r. odmówił emerytowi ponownego przeliczenia procentowego wymiaru emerytury wojskowej (pierwotną decyzję wydano 4 sierpnia 2016 r.). Wnioskował on o ponowne rozpatrzenie wysokości emerytury, podnosząc, że nieprawidłowo wyliczono mu liczbę miesięcy pełnienia służby na froncie, co wpływa na obniżenie emerytury.

Wnioskodawca wskazał, że pełnił służbę w Polskim Kontyngencie Wojskowym w Składzie Międzynarodowych Sił Stabilizacyjnych w Republice Iraku w okresach:

- 3 sierpnia 2004 r. - 10 lutego 2005 r.,

- 22 stycznia 2006 r. - 25 lipca 2006 r.,

- 29 lipca 2007 r. - 2 lutego 2008 r.

9 K. Jasicki, Byli oficerowie na rynku pracy we Wrocławiu w XXI wieku, „Zeszyty Naukowe Wyższej Szkoły Oficerskiej Wojsk Lądowych im. gen. T. Kościuszki” 2011, nr 4(162), s. 460-473; P. Rasmus, D. Makowska, A. Stetkiewicz-Lewandowicz, T. Sobów, W. Machała, Poczucie koherencji a występowanie zaburzeń po stresie traumatycznym $w$ grupie zawodowych żołnierzy uczestniczq̨cych $w$ misji wojskowej poza granicami kraju - doniesienie wstępne, „Anestezjologia i Ratownictwo” 2013, nr 7, s. 27-36. 
Ani Dyrektor Wojskowego Biura Emerytalnego, ani sąd nie kwestionowali długości okresu służby w kontekście § 4 Rozporządzenia Rady Ministrów z dnia 15 lipca 2011 r. w sprawie szczegółowych warunków podwyższania emerytur wojskowych ${ }^{10}$. Służba ta spełniała warunki do jej uznania za służbę na froncie w czasie wojny lub w strefie działań wojennych (art. 15 ust. 3 ustawy o zaopatrzeniu emerytalnym żołnierzy). Za okoliczności bezsporne uznano nie tylko okres tej służby, ale i służby pozostałej będącej podstawą do wyliczenia emerytury.

Dyrektor Wojskowego Biura Emerytalnego uznał, że suma okresów pełnienia służby przez wnioskodawcę na misjach wyniosła 18 miesięcy i 17 dni. W myśl obowiązujących przepisów zwiększenie z tego tytułu przysługuje w wysokości 9,50\% (za 19 miesięcy). Dyrektor, wyliczając wartość zwiększenia, powołał się na wspomniany § 26 ust. 1 rozporządzenia Ministra Obrony Narodowej z dnia 10 lutego 2012 r. w sprawie trybu postępowania i właściwości organów w sprawach zaopatrzenia emerytalnego żołnierzy zawodowych oraz uprawnionych członków ich rodzin. Obliczając wysługę emerytalną, zsumował poszczególne okresy o jednakowym procentowym wskaźniku (innego w tym przypadku nie było), następnie sumę dni zamienił się na miesiące, przyjmując za miesiąc trzydzieści dni kalendarzowych. W końcowym podsumowaniu okresy niepełnych miesięcy uwzględnił, na co enumeratywnie wskazuje przytoczony przepis.

Wnioskodawca złożył w dniu 10 listopada 2017 roku odwołanie. Wniósł o uchylenie zaskarżonej decyzji w całości i ponowne przeliczenie wartości emerytury, z uwzględnieniem każdego rozpoczętego miesiąca pełnienia służby $\mathrm{w}$ strefie działań wojennych, wnosząc tym samym o podwyższenie emerytury o 11\%. Wnioskodawca podniósł, że jego zdaniem, organ emerytalny nieprawidłowo ustalił, że taką służbę pełnił przez 1 rok 6 miesięcy i 17 dni.

10 Dz.U. z 2011 r. Nr 159, poz. 946. 
Wnioskodawca wniósł o przyjęcie, że pełnił służbę wojskową w warunkach szczególnych w następującym wymiarze:

1) w okresie od 3 sierpnia 2004 r. do 10 lutego 2005 r. - 7 miesięcy (gdzie sierpień i luty są miesiącami rozpoczętymi),

2) w okresie od 22 stycznia 2006 r. do 25 lipca 2008 r. - 7 miesięcy (gdzie styczeń i lipiec są miesiącami rozpoczętymi),

3) w okresie od 29 lipca 2007 r. do 2 lutego 2008 r. - 8 miesięcy (gdzie lipiec i luty są miesiąca rozpoczętymi).

Wnioskodawca uznał, że jego służba wojskowa trwała 22 miesiące, a uwzględniając zwiększenie za każdy rozpoczęty miesiąc służby w wysokości 0,5\%, emerytura powinna zostać zwiększona o 11\%. W odpowiedzi na odwołanie Dyrektor Wojskowego Biura Emerytalnego wniósł o jego oddalenie, podnosząc argumenty jak w zaskarżonej decyzji.

Sąd Okręgowy w Łodzi uznał, że odwołanie zasługuje na uwzględnienie i skutkuje zmianą zaskarżonej decyzji. Przyjęto, że okresy te, zgodnie z odwołaniem, należy uznawać rozłącznie, a de facto sumowanie poszczególnych dni trzech odrębnych okresów służby w tej strefie i zamianie ich na pełne miesiące jest niewłaściwe. Sąd wywiódł również, że zaskarżona decyzja została wydana z naruszeniem zarówno przepisów art. 15 ust. 3 ustawy z dnia 10 grudnia 1993 r. o zaopatrzeniu emerytalnym żołnierzy zawodowych oraz ich rodzin, § 4 ust. 1 pkt 2 rozporządzenia Rady Ministrów z dnia 15 lipca 2011 r. w sprawie szczegółowych warunków podwyższania emerytur wojskowych, jak i § 26 ust. 1 rozporządzenia Ministra Obrony Narodowej z dnia 10 lutego 2012 r.

Sąd Okręgowy w Łodzi uznał na podstawie § 26 ust. 1 rozporządzenia Ministra Obrony Narodowej z dnia 10 lutego 2012 r. w sprawie trybu postępowania i właściwości organów w sprawach zaopatrzenia emerytalnego żołnierzy zawodowych oraz uprawnionych członków ich rodzin, że „każdy rozpoczęty miesiąc służby powoduje podwyższenie podstawy wymiaru świadczenia niezależnie od tego, ile dni w tym miesiącu służba była pełniona”, odnosząc się w tym kontekście do przepisów ustawy o zaopatrzeniu emerytalnym żołnierzy, które w art. 15 ust. 3 stanowią, że za każdy rozpoczęty miesiąc pełnienia służby na froncie w czasie wojny lub w strefie działań wojennych podwyższa się emeryturę o 0,5\% pod- 
stawy wymiaru. Jednak ustawodawca wprowadził przepis (art. 15 ust. 6a ustawy o zaopatrzeniu emerytalnym żołnierzy), że to Rada Ministrów określi, w drodze rozporządzenia, szczegółowe warunki podwyższania emerytury, a tym samym sposób obliczania liczby miesięcy.

Tymczasem w rozporządzeniu wydanym przez Ministra Obrony Narodowej 10 lutego 2012 r. ustalono (§ 26 ust. 1), że w końcowym podsumowaniu okresy niepełnych miesięcy nie są uwzględniane, z wyjątkiem okresów, o których mowa w art. 15 ust. 3 ustawy o zaopatrzeniu emerytalnym żołnierzy. W zdaniach poprzedzających wskazany przepis znajdują się regulacje dotyczące ustalania wysługi emerytalnej i informacje o odpowiednim sumowaniu poszczególnych okresów. Dopiero na końcu przepisu znajduje się sformułowanie „w końcowym podsumowaniu”, które odnosi się do wysługi lat. Zwrot ten jednoznacznie sugeruje, że sumowanie powinno nastąpić na finalnym, ostatecznym etapie ustalania wartości wysługi emerytalnej.

W związku z powyższym uznawanie każdego rozpoczętego miesiąca służby za uprawniający do podwyższenia wymiaru świadczenia może być niewłaściwe. Uwzględnienie niepełnych miesięcy powinno nastąpić bowiem dopiero na ostatnim etapie wyliczania okresu służby, bez względu na metodę obliczania tego okresu (sposób obliczania tego okresu może także powodować wątpliwości - patrz dalsza część niniejszego artykułu).

\section{Inne wyroki w omawianej kwestii}

Na wstępie zwrócić uwagę należy zwłaszcza na wyrok Sądu Okręgowego w Białymstoku z dnia 17 marca 2014 r. ${ }^{11}$, w którym przyjęto, że najistotniejszy w niniejszej sprawie jest kilkukrotnie przedstawiany § 26 Rozporządzenia Ministra Obrony Narodowej z dnia 10 lutego 2012 r. w sprawie trybu postępowania i właściwości organów w sprawach zaopatrzenia emerytalnego żołnierzy zawodowych oraz uprawnionych członków ich rodzin. Zdaniem sądu przepis ten - który mógłby wskazywać na łączne liczenie poszczególnych okresów - nie ma podstawy prawnej, gdyż wskazane

11 V U 68/14, Lex nr 1722294. 
rozporządzenie wydano na podstawie art. 37 ustawy o zaopatrzeniu emerytalnym żołnierzy. Chodziło tu dokładnie o przekroczenie przez Ministra Obrony Narodowej zakresu delegacji ustawowej. Nadto, jako przepis pozbawiony podstawy ustawowej uznał go za niekonstytucyjny ${ }^{12}$ zgodnie z art. 178 ust. 1 Konstytucji Rzeczypospolitej Polskiej ${ }^{13}$. Sąd odwołał się tu do wskazówek wyrażonych przez Trybunał Konstytucyjny w akapicie czwartym punktu 1. części III. uzasadnienia wyroku tego Trybunału z dnia 23 kwietnia 2013 r. w sprawie P. 44/2010. W punkcie tym czytamy, że sędziowie podczas orzekania podlegają tylko Konstytucji oraz ustawom, co oznacza, że nie ma przeszkód formalnych, aby bez zwracania się do Trybunału Konstytucyjnego z pytaniem prawnym sprawę rozstrzygnąć z pominięciem przepisów wskazanego rozporządzenia.

Sąd wskazał, że przepis ustawy o zaopatrzeniu emerytalnym żołnierzy, w oparciu o który to rozporządzenie wydano, czyli art. 37 ustawy o zaopatrzeniu emerytalnym żołnierzy, upoważniał Ministra Obrony Narodowej do określenia:

1) trybu postępowania i właściwości organów w sprawach zaopatrzenia emerytalnego żołnierzy oraz uprawnionych członków ich rodzin, wskazując elementy wniosku o ustalenie prawa do zaopatrzenia, dowody niezbędne do ustalenia prawa do świadczenia oraz sposób i terminy wypłaty świadczeń,

2) wzoru i trybu wydawania legitymacji emeryta-rencisty wojskowego, uwzględniając organ uprawniony do wydawania, wymiany i dokonywania wpisów, w tym wpisu o niezdolności do samodzielnej egzystencji, oraz przypadki wymiany legitymacji.

Tymczasem określony w § 26 sposób obliczania wysługi lat nie mieści się w zacytowanej delegacji. Ponadto art. 15 ust. 3 i 5 ustawy o zaopatrzeniu emerytalnym żołnierzy odnoszą się do wysokości emerytury

Zob. szersze wywody w tym zakresie w uzasadnieniu wyroku.

13 Szerzej o sądowej kontroli konstytucyjności aktów prawa w: N. Fox, A. Ozimek, Sqqdowa kontrola konstytucyjności aktów prawa miejscowego - wyłom w systemie czy egzemplifikacja konkretnej kontroli konstytucyjności w polskim porzq̨dku prawnym?, „Zeszyty Naukowe Towarzystwa Doktorantów UJ. Nauki Społeczne” 2017, nr 17, s. 49-69. 
i podstawy wymiaru, a § 26 rozporządzenia precyzuje obliczanie wysługi emerytalnej.

W uzasadnieniu sąd wskazał, że art. 15 ust. 5 ustawy o zaopatrzeniu emerytalnym żołnierzy stwierdza, że „Przy ustalaniu prawa do emerytury i obliczaniu jej wysokości okresy, o których mowa w ust. 1 i $2^{14}$, ustala się z uwzględnieniem pełnych miesięcy”. Jak wspomniano na wstępie, w ustępach 1 i 2 opisane są procentowe wysokości wzrostu emerytury za pozostałe, preferowane przez ustawodawcę okresy. Z zestawienia wskazanych przepisów sąd wywiódł wniosek, że ust. 5., nie wymieniając służby wymienionej w ust. 3., czyli „na froncie w czasie wojny lub w strefie działań wojennych”, wskazuje na uwzględnianie również niepełnych miesięcy. W związku $\mathrm{z}$ powyższym do wyliczenia zwiększenia z tytułu pełnienia służby w strefie działań wojennych należy wprost stosować art. 15 ust. 3 ustawy z dnia 10 grudnia 1993 r. o zaopatrzeniu emerytalnym żołnierzy zawodowych oraz ich rodzin, który wskazuje na każdy rozpoczęty miesiąc pełnienia służby na froncie w czasie wojny lub w strefie działań wojennych jako na pozwalający na podwyższenie podstawy wymiaru emerytury o 0,5\%. Należy jednak podkreślić, że w ustępach 1 i 2 jest odwołanie do lat służby, a odwołanie do pełnych miesięcy znajdujące się w ust. 5, jest dookreśleniem sposobu obliczania wskazanych lat, a nie miesięcy, o których jest mowa dopiero w istotnym w niniejszym artykule ust. 3.

Apelację organu rentowego we wskazanej sprawie w całości oddalił Sąd Apelacyjny w Białymstoku w wyroku z dnia 29 października 2014 r. ${ }^{15}$ Sąd, dokonując oceny zaistniałego stanu faktycznego i nie kwestionując konstytucyjności wskazanego rozporządzenia, zaakcentował, że treść przepisów nie pozostawia wątpliwości i na podstawie art. 15 ust. 3 ustawy o zaopatrzeniu emerytalnym żołnierzy, § 4 rozporządzenia Rady Ministrów z dnia 15 lipca 2011 r. w sprawie szczegółowych warunków podwyższania emerytur wojskowych oraz § 26 ust. 1 rozporządzenia Mi-

14 Pominięcie w tej regulacji (art. 15 ust. 5 ustawy o zaopatrzeniu emerytalnym żołnierzy) służby w trakcie urlopu wychowawczego (ust. 1a ustawy o zaopatrzeniu emerytalnym żołnierzy) wskazuje na możliwość uznawania również i w tym przypadku niepełnych miesięcy.

III AUa 756/14, Lex nr 1544639. 
nistra Obrony Narodowej z dnia 10 lutego 2012 r. w sprawie trybu postępowania i właściwości organów w sprawach zaopatrzenia emerytalnego żołnierzy zawodowych oraz uprawnionych członków ich rodzin, można uznać, że każdy rozpoczęty miesiąc służby w strefie działań wojennych powoduje podwyższenie podstawy wymiaru świadczenia niezależnie od tego, ile dni w tym miesiącu służba była pełniona.

W innej sprawie zakończonej wyrokiem Sądu Okręgowego w Gdańsku z dnia 18 września 2017 r. ${ }^{16}$ rozpatrywano odwołanie od decyzji Dyrektora Wojskowego Biura Emerytalnego, mocą której odmówiono żołnierzowi podwyższenia podstawy wymiaru świadczenia z tytułu pełnienia służby na froncie podczas wojny lub w strefie działań wojennych z 6,5\% do 7,5\%. W uzasadnieniu decyzji wskazano, iż zgodnie z przepisami art. 15 ust. 3 ustawy z dnia 10 grudnia 1993 r. o zaopatrzeniu emerytalnym żołnierzy zawodowych oraz ich rodzin, a także $\S 4$ rozporządzenia Rady Ministrów z dnia 15 lipca 2011 r. w sprawie szczegółowych warunków podwyższania emerytur wojskowych przy obliczaniu wysługi emerytalnej sumuje się poszczególne okresy o jednakowym procentowym wskaźniku, obejmujące lata, miesiące i dni - sumę dni zamienia się na miesiące przy przyjęciu pełnych 30 dni jako miesiąca, sumę miesięcy zaś zamienia się lata przy przyjęciu pełnych 12 miesięcy za jeden rok. Wynika z tego, iż w końcowym podsumowaniu okresy niepełnych miesięcy nie są uwzględniane, $\mathrm{z}$ wyjątkiem okresów, o których mowa w art. 15 ust. 3 ustawy o zaopatrzeniu emerytalnym żołnierzy. Wnioskodawcy z tytułu pełnienia służby w strefie działań wojennych przez okres 1 roku i 26 dni podwyższono emeryturę wojskową o 6,50\% tj. za okres 13 miesięcy. Sąd Okręgowy przyjął, że w oparciu o przepisy art. 15 ust. 3 ustawy o zaopatrzeniu emerytalnym żołnierzy w związku z § 4 ust. 1 punkt 2 rozporządzenia z 2011 r. w związku z § 26 ust. 1 zdanie czwarte rozporządzenia wykonawczego z 2012 r. do ustalenia ubezpieczonemu wymiaru świadczenia z tytułu pełnienia służby na froncie podczas wojny lub w strefie działań wojennych należało uwzględnić nie tylko konkretne okresy służby na froncie w czasie wojny lub w strefie działań wojennych ubezpieczone-

16 VII U 3283/17, Lex nr 2380399. 
go, ale także, co wynika z § 26 ust. 1 zdanie czwarte rozporządzenia wykonawczego z 2012 r., pełne miesiące takiej służby. Powyższe obliczenie powoduje wzrost liczby miesięcy pełnienia służby przez ubezpieczonego w omawianej sprawie o 2 miesiące, co w kontekście przelicznika 0,5\% za każdy miesiąc (art. 15 ust. 3 ustawy o zaopatrzeniu emerytalnym żołnierzy) oznacza, iż podstawa wymiaru świadczenia z tytułu pełnienia służby na froncie podczas wojny lub w strefie działań wojennych dla żołnierza powinna zostać ustalona na poziomie 1 punktu procentowego wyżej, niż to miało miejsce w decyzji.

Co się tyczy pozostałych orzeczeń, to w wyroku Sądu Apelacyjnego w Białymstoku z dnia 2 grudnia 2014 r. ${ }^{17}$ przyjęto, że w przypadku służby w strefie działań wojennych każdy rozpoczęty miesiąc służby powoduje podwyższenie podstawy wymiaru świadczenia, niezależnie od tego, ile dni w tym miesiącu służba była pełniona, co nie stanowi naruszenia art. 15 ust. 3 ustawy o zaopatrzeniu emerytalnym żołnierzy oraz $\S 4$ rozporządzenia Rady Ministrów w sprawie szczegółowych warunków podwyższania emerytur wojskowych z 2011 r. Analogiczne stanowisko przyjął Sąd Okręgowy w Łodzi w jednym z najnowszych judykatów dotyczących omawianego zagadnienia, a mianowicie $\mathrm{w}$ wyroku $\mathrm{z}$ dnia 8 czerwca $2018 \mathrm{r}^{18}$, uznając, że podstawą rozstrzygnięcia jest przepis $\S 26$ ust. 1 rozporządzenia Ministra Obrony Narodowej z dnia 10 lutego 2012 r. w sprawie trybu postępowania i właściwości organów w sprawach zaopatrzenia emerytalnego żołnierzy zawodowych oraz uprawnionych członków ich rodzin, które to rozporządzenie obowiązuje od dnia 7 marca 2012 r. W przepisie tym w sposób jasny wskazano, iż okresy niepełnych miesięcy nie są uwzględniane, z wyjątkiem okresów, o których mowa w art. 15 ust. 3 ustawy o zaopatrzeniu emerytalnym żołnierzy. W uzasadnieniu wyroku Sądu Apelacyjnego w Rzeszowie z dnia 19 grudnia 2012 r. ${ }^{19}$ czytamy z kolei, że przewidziane w art. 15 ust. 3 ustawy z dnia 10 grudnia 1993 r. o zaopatrzeniu emerytalnym żołnierzy zawodowych oraz ich rodzin podwyższenie emerytury, m.in. z tytułu tak określonej

17 III AUa 898/14, Lex nr 1623819.

18 VIII U 831/18, Lex nr 2515026.

19 III AUa 905/12, Lex nr 1240082. 
służby w sposób autonomiczny i wyczerpujący regulowało zasady wyliczenia tego zwiększenia, stanowiąc wprost, że emeryturę podwyższa się o 0,5\% podstawy wymiaru za każdy rozpoczęty miesiąc pełnienia służby.

\section{Podsumowanie}

Powołany na wstępie wyrok Sąd Okręgowego w Łodzi - przedstawiony zwłaszcza w kontekście wyroku Sądu Okręgowego w Białymstoku w sprawie V U 68/14 - pokazuje, jak pozornie techniczna i rachunkowa kwestia urosła do zasadniczego problemu stosowania prawa w zakresie zabezpieczenia emerytalnego żołnierzy. Rozdźwięk widoczny jest tu już na poziomie stosowania ustawy o zaopatrzeniu emerytalnym żołnierzy przez Wojskowe Biura Emerytalne (które opierają swe decyzje na, wywołującym słuszne wątpliwości co do przekroczenia zakresu delegacji ustawowej, rozporządzeniu wykonawczym z 2012 r.) oraz sądy powszechne (które zaś wyrokują przeważnie na podstawie art. 15 ust. 5 ustawy o zaopatrzeniu emerytalnym żołnierzy, traktując ten przepis jak normę pełną i kompleksową, co również wywołuje wątpliwości). Sądy, kwestionując bowiem podstawę prawną rozporządzenia z 2012 r., dokonują wykładni sądowej i ustalają wysokość emerytury wyłącznie na podstawie wspomnianego art. 15 ust. 3. Na podstawie tego przepisu można jednak pobyt w strefie wojny analizować w pełnych miesiącach, ale licząc w odmienny sposób niż zaakceptowany przez sąd w Łodzi, tj. od dnia rozpoczęcia danego okresu, ale uwzględniając kolejne następujące dni, a nie miesiące kalendarzowe. Licząc „każdy rozpoczęty miesiąc pełnienia służby” w ten sposób jako kolejno następujące po sobie 30 dni, w powołanym na wstępie niniejszego wyroku Sądu Okręgowego w Łodzi można otrzymać następującą liczbę miesięcy:

1) w okresie od 03 sierpnia 2004 r. do 10 lutego 2005 r. -7 miesięcy,

2) w okresie od 22 stycznia 2006 r. do 25 lipca 2006 r. - 7 miesięcy,

3) w okresie od 29 lipca 2007 r. do 02 lutego 2008 r. - 7 miesięcy (a nie 8 miesięcy, jak uznał sąd). 
W przypadku uwzględnienia przy liczeniu liczby miesięcy faktycznej liczby dni służby, otrzymujemy 191, 184 oraz 188 dni, a więc ponownie 7, 7 oraz 7 miesięcy.

Przedstawione powyżej metody mogą być równie poprawne, stosowana przez sądy ustawa o zaopatrzeniu emerytalnym żołnierzy bowiem nie precyzuje, jak „każdy miesiąc” liczyć. Zgodnie z wieloma regulacjami prawnymi „miesiąc liczy się za dni trzydzieści” (art. 114 Kodeksu cywilnego) lub jako „miesiąc kalendarzowy” (np. art. 43 ustawy z dnia 25 czerwca 1999 r. o świadczeniach pieniężnych z ubezpieczenia społecznego $\mathrm{w}$ razie choroby i macierzyństwa). Tymczasem ustawodawca w tym przypadku w ustawie o zaopatrzeniu emerytalnym żołnierzy precyzyjnie nie dookreślił konkretnej metody liczenia, pozostawiając regulacje rozporządzeniu Rady Ministrów, które tego jednak również nie definiuje. Najczęściej stosowane w tej materii rozporządzenie Ministra Obrony Narodowej, zdaniem wielu sądów, w tym Sądu Okręgowego w Białymstoku, jest niekonstytucyjne.

Przepisy prawne wynikające z obowiązującego rozporządzenia Ministra Obrony Narodowej z 2012 r. precyzują i wprost określają sumowanie poszczególnych okresów służby i dopiero w końcowym podsumowaniu uwzględnienie niepełnych miesięcy. Tymczasem regulacje wynikające z ustawy o zaopatrzeniu emerytalnym żołnierzy, a także z rozporządzenia wydanego na podstawie art. 15 ust. 6a ustawy (a w zasadzie brak takich regulacji w przedmiotowym rozporządzeniu) wskazują na konieczność uwzględniania każdego rozpoczętego miesiąca. Jednak brak w nich o czym wspomniano powyżej - regulacji w zakresie sposobu obliczania tych miesięcy, nie pozostawia wątpliwości w zakresie konieczności odwoływania się do wskazanego rozporządzenia z 2012 r. Uznając konstytucyjność tego rozporządzenia ${ }^{20}$, należy uznać, że przedstawione argumenty uprawniają do szerszego odniesienia się do zasad wyliczenia emerytury w niniejszym tekście.

Pozostaje mieć nadzieję, że ustawodawca ostatecznie dostrzeże powyższe problemy i rozstrzygnie je stosowną interwencją legislacyjną. Zasa-

20 M. Gutowski, P. Kardas, Domniemanie konstytucyjności a kompetencje sq̨dów, „Palestra” 2016, nr 61(5), s. 44-62. 
dy i kryteria pozwalające ustalić wysokość emerytury wojskowej powinny zostać ujęte w postaci przepisu rangi ustawowej. Nie trudno bowiem o konstatację, że kwestia obliczania wysokości emerytury żołnierzy, głównie w kontekście liczenia okresu pełnienia służby na froncie w czasie wojny lub w strefie działań wojennych, wymaga doprecyzowania.

\section{Bibliografia:}

Babińska R., Systemowe zagadnienia zabezpieczenia emerytalnego wojskowych, „Acta Universitatis Wratislaviensis” 2008, nr 3079, s. 261-273.

Czechowski M., Prawny charakter zatrudnienia żołnierzy zawodowych, TNOiK, Toruń 2016.

Fox N., Ozimek A., Sq̨owa kontrola konstytucyjności aktów prawa miejscowego - wyłom w systemie czy egzemplifikacja konkretnej kontroli konstytucyjności w polskim porzqdku prawnym?, „Zeszyty Naukowe Towarzystwa Doktorantów UJ. Nauki Społeczne” 2017, nr 17, s. 49-69.

Gutowski M., Kardas P., Domniemanie konstytucyjności a kompetencje sq̨dów, „Palestra” 2016, nr 61(5), s. 44-62.

Jasicki K., Byli oficerowie na rynku pracy we Wrocławiu w XXI wieku, „Zeszyty Naukowe Wyższej Szkoły Oficerskiej Wojsk Lądowych im. gen. T. Kościuszki” 2011, nr 4(162), s. 460-473.

Koczur W., Zaopatrzenie emerytalne służb mundurowych jako element systemu zabezpieczenia społecznego, „Studia Ekonomiczne” 2017, nr 312, s. 51-55.

Kuźma P., Jakie zmiany w wojskowym systemie emerytalnym?, „Praca i Zabezpieczenie Społeczne” 2010, nr 3, s. 10-16.

Rasmus P., Makowska D., Stetkiewicz-Lewandowicz A., Sobów T., Machała W., Poczucie koherencji a występowanie zaburzeń po stresie traumatycznym w grupie zawodowych żołnierzy uczestniczqcych w misji wojskowej poza granicami kraju - doniesienie wstępne, „Anestezjologia i Ratownictwo” 2013, nr 7, s. 27-36.

Walczak D., Przywileje emerytalne - aspekt społeczno-ekonomiczny, „Studia Oeconomica Posnaniensia” 2017, nr 5(10), s. 49-52.

Wantoch-Rekowski, J., System ubezpieczeń społecznych a budżet państwa: studium prawnofinansowe, Wolters Kluwer, Warszawa 2014. 